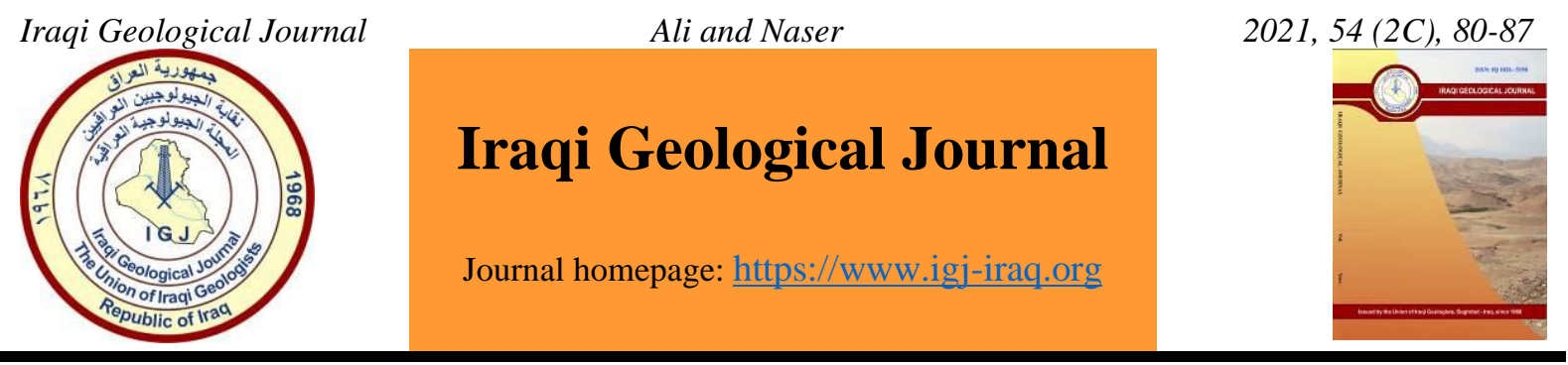

\title{
Potential Source of Heavy Metals in the Geophagic Clay (Marl) and Its Implication on Human Health in NE Iraq: A Pilot Study
}

\author{
Abbas R. Ali ${ }^{1}{ }^{*}$ and Sarah I. Naser ${ }^{2}$ \\ Department of Geography, College of Education for Humanities Science, University of Kirkuk, Kirkuk, Iraq \\ Department of Applied Geology, College of Science, University of Kirkuk, Kirkuk, Iraq \\ * Correspondence: abbaskervanci@uokirkuk.edu.iq
}

Received: 5 April 2021; Accepted: 8 July 2021; Published: 30 September 2021

\begin{abstract}
Geophagy is the eating of non-food earthy matters practice (such as clay), which is performed especially in humans, to augment a scanty or mineral-deficient diet or as part of a cultural tradition. Geophagy, the intentional ingestion of clay or soil, is a prevalent practice among animals and humans, especially is more common in young ages, such as children and among pregnant women with a young age. In spite of some well documented cases, the motivations of this practice and its consequences on the status of health of the consumer are still unclear. This study focused on the source of heavy metals and its health impact because of the importance of the topic in the environmental hazards, especially as this addictive phenomenon may not be well known among families in our societies. During this study, twenty-four samples of marl were collected within the rock sequences of the Fatha Formation in the Kirkuk and Diyala, which are used in eating (mud eating disease) in these regions. The samples were subjected to laboratory studies including chemical analyses, to determine their contents of trace elements. The laboratory analytical data showed that these muds (marl) contain different concentrations of chemical elements such as $(\mathrm{Co}, \mathrm{Cr}, \mathrm{Ni}, \mathrm{Cu}$, and $\mathrm{Zn})$ which are among the heavy toxic elements and harmful to human health. A close look at the analytical data and results of the statistical and environmental factors, it is found that the marl (geophagia) consumption in terms of its content of trace elements, poses health risks to the consumer. However, it is worth mentioning to say that Geophagia practice may contribute large levels of the most beneficial elements such as $\mathrm{Ca}, \mathrm{Fe}, \mathrm{K}, \mathrm{Na}, \mathrm{Cu}$, and $\mathrm{Zn}$, supplying in demand mineral nutrients in the human body.
\end{abstract}

Keywords: Geophagia; Marl; Iraq; Mineralogy; Environmental indices; Health impact

\section{Introduction}

The term geophagy (or Geophagia) has been applied in 1850 to humans and animals' practice of soil consuming, it is a type of pica which refers when a person craves or eats nonfood items, such as earth eating conduct and has been accounted for among pre-school kids, pregnant ladies, and it rarely occurs in adults (Reid, 1992; Henry and Cring, 2012; Gupta, 2019; Al-Hamdani et al., 2016). Even though this practice is found in all continents, it is most trendy seen in the tropics, particularly in tropical Africa (Dissanayake \& Chandrajith, 2009). The evidence suggested that the practice is not limited to poor societies but cuts across socio-economic, religious, ethnic and racial divides (Ekosse \& Jumbam, 2010). Typically, only specific soils are consumed and are chosen for wanted characteristics for instance

DOI: 10.46717/igj.54.2C.8Ms-2021-09-27 
color, flavor, odor, plasticity and texture (Vutchkov et al., 2013). There is a relationship between geophagia and pregnancy, including medical causes, beliefs and traditions. In southern Africa, a pregnant woman thinks that eating clay is beneficial for the fetus because it makes their skin smooth and beautiful (Ekosse \& Jumbam, 2010), In Iraq, some pregnant women eat mud to have a healthy baby. Clay is not only eaten by pregnant women; it is also eaten by some people to treat stomach diseases and ulcers and is used as a treatment for hair loss and clear skin (Monaco et al., 2019).

The main reasons for geophagia are to detoxify harmful or unpalatable compounds in the diet, relieve gastrointestinal disturbances such as diarrhea, supplement the diet with mineral nutrients, and relieve excess acidity in the digestive system (Wilson, 2003) and it can be a good source of calcium, manganese and magnesium (Hooda et al., 2004). However, it may also be harmful, by causing intestinal effects, reducing the bio-availability of beneficial micronutrients, and introducing toxic substances such as lead or by acting as a carrier of geohelminth infection (Pain et al., 2018). Depending on the amount and type of substance being eaten, complications such as malnutrition, developmental delay, parasitic infections and poisoning can be observed (Çakar and Şener, 2009), In addition to that it causes a decrease in iron absorption thus leads to a decrease in hemoglobin and severe anemia (Hooda et al., 2002; Alanazi et al., 2018). It was observed by visiting the health centers and meeting with a group of doctors in these centers in Kirkuk and Diyala governorates, that there are sick cases related to the practice of eating mud among some of the patients, especially women and children. Accordingly, we decided to conduct this study to show the extent of the impact of the chemical content of these clays and the problems resulting from eating them on public health. Whereas, there are no local studies about this topic at the present time, so this is the first paper dealing with the study of this field. The objectives of this study are determining the chemical compositions of marl and mud rocks of the Fatha Formation that are used for eating (geophagia); and evaluate the trace elements contamination levels based on geo-accumulation index (Igeo) and calculation of oral intake of trace elements from geophagic marl by using health risk index (HRI).

\section{Location and Geological Setting}

The study area is located in northeastern Iraq within the low folded zone of the unstable shelf of the tectonic division of Iraq at Kirkuk and Diyala (Fig 1). It is represented by marl outcrops of the Fatha Formation. The study area includes specific locations from the Laylan area, which is $19 \mathrm{~km}$ southeast of Kirkuk, and the Kiwan region, $10 \mathrm{~km}$ northwest of Kirkuk, and includes specific sites from the Kifri region, which is about $100 \mathrm{~km}$ north of Diyala. Kirkuk is about $9679 \mathrm{~km}$, and it is located geographically between the longitude ( $\left.44^{\circ} 18^{\prime} 0^{\prime \prime}\right)$ and ( $\left.44^{\circ} 26^{\prime} 30^{\prime \prime}\right)$ and latitude ( $\left.35^{\circ} 31^{\prime} 30^{\prime \prime}\right)$ and ( $\left.35^{\circ} 22^{\prime} 30^{\prime \prime}\right)$, its average height above the sea level is about $300 \mathrm{~m}$. Diyala is about $17685 \mathrm{~km}$, and it is located geographically

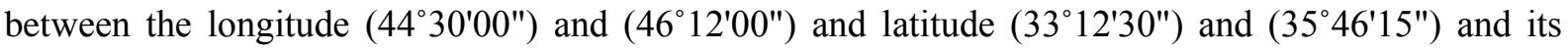
average height above the sea level is about $232 \mathrm{~m}$.

The area consists of several geological formations, the most important of which are the Fatha, Injana, Mukdadiya and Bai-Hassan formations (Fig. 1). The Fatha Formation consists of limestone, marl, anhydrite, gypsum, and fine-grained clastic, with $900 \mathrm{~m}$ thickness in the center of the depositional basin, (Al-Naqib, 1960). It is deposited in the environment of high salinity coastal lakes, and this is reflected by the presence of gypsum layers and the presence of fossils in the limestone rocks, whereas, the abundance of shell fragments that form the barriers and ridges reflects a calm (low energy) marine environment, while the soil crumb material increases and evaporation decreases when the formation is deposited near the coast. The Injana Formation is characterized by the heterogeneity of lithology, but the basic units consist largely of marlstone or mudstones and siltstones of red or gray color, as well as sandstone layers with granular sizes ranging from medium to coarse. The Mukdadiya Formation consists mainly of fine gravel deposits and coarse-grained sandstone and siltstone, pebbly sandstone and 
conglomerate as thin lenses in the upper part of the formation. Bai Hassan Formation is very similar to the deposition of the Mukdadiya Formation, but they differ in the granular size of the deposit, as the deposition of the Bai Hassan Formation in general, have large sizes.

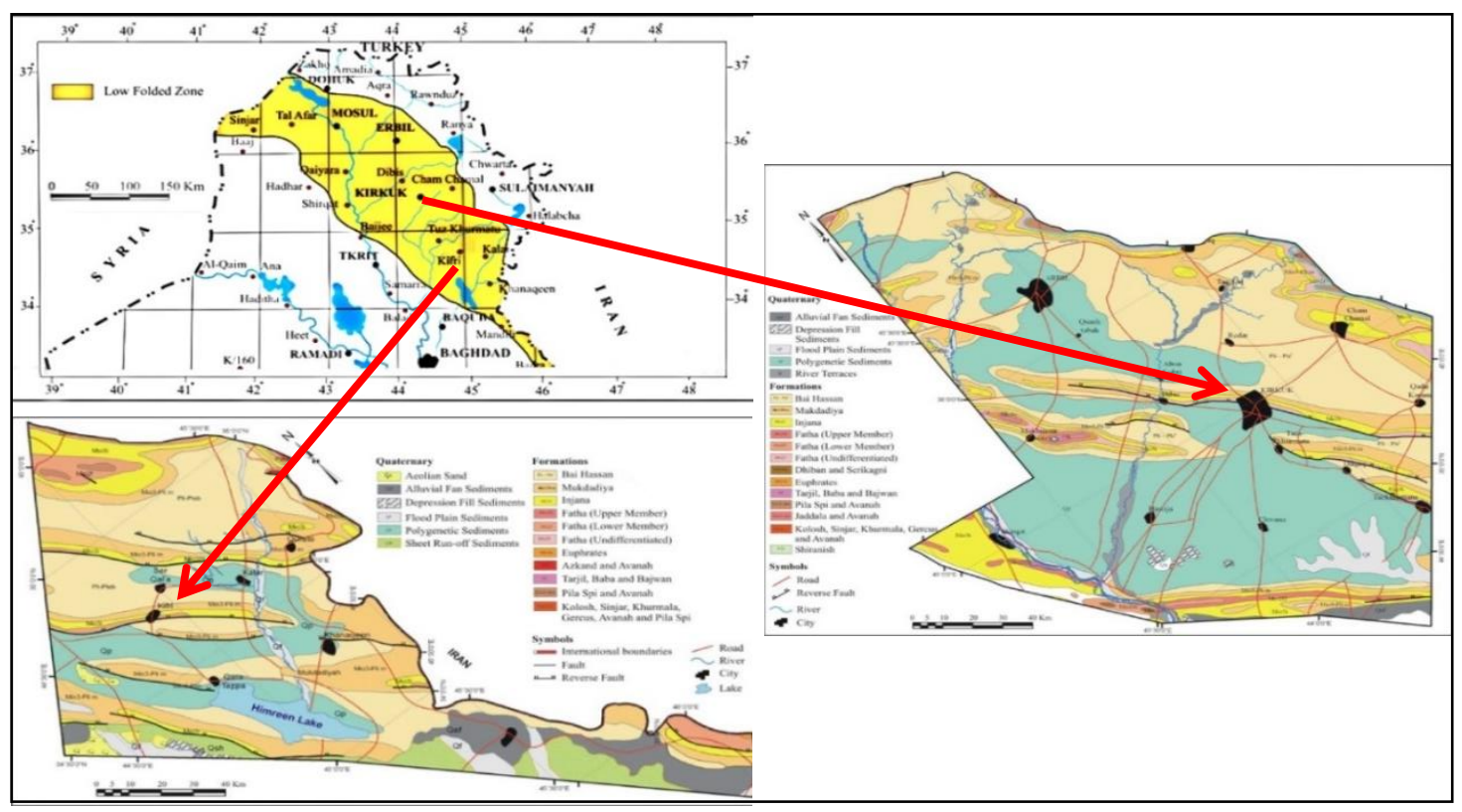

Fig.1. Geological map of northern Iraq showing the location of the studied area

\section{Materials and Methods}

\subsection{Sampling and Chemical Analysis}

Twenty-four samples of exposed marl were collected from the Fatha Formation, including five samples from Laylan region, five samples from the Kiwan region belonging to Kirkuk, six samples from the Kifri region of Diyala and eight samples from the markets, five of them from Dibs and three from Kifri (Table 1). The geophagy marl was analyzed for $\mathrm{Co}, \mathrm{Ni}, \mathrm{Cu}, \mathrm{Cr}$ and $\mathrm{Zn}$ using the energy dispersive $\mathrm{X}$-ray fluorescence (PEDXRF) techniques in Turkey. Samples were dried by the sun and then ground into fine powder in agate mortar. Samples were sieved to pass through of $200 \mu \mathrm{m}$, and then pressed into thick pellets of $32 \mathrm{~mm}$ diameter using watch as blinder. USGS standards, GBW 7109, GEOL and GBW-7309 Sediment equally pressed into pellets in a similar manner as the samples, and these used for quality assurance (Timothy and La, 1989; Johnson et al., 1999).

\subsection{Assessment Indices}

\subsubsection{Geoaccumulation Index (Igeo)}

This indicator is used to determine the pollution of trace elements in sediment samples (Haris et al., 2017). The equation was presented by Muller (1979) as a measure of the severity of pollution, by comparing the current concentration with background levels. It can be calculated according to the following equation (Muller, 1979):

$$
I_{\text {geo }}=\log _{2} \frac{C n}{B n * 1.5}
$$

Where $\mathrm{Cn}$ is the measured concentration of trace element in the marl sample; $\mathrm{Bn}$ is the reference value or geochemical background concentration of the trace element (Mason, 1966), and the factor 1.5 
in this equation is to reduce the effect of possible differences in background values Bn (Lar et al., 2014). The index of Geo-accumulation (Igeo) is classified into seven classes by Muller (1969) (Table 2).

Table 1. Location sites in the studied area

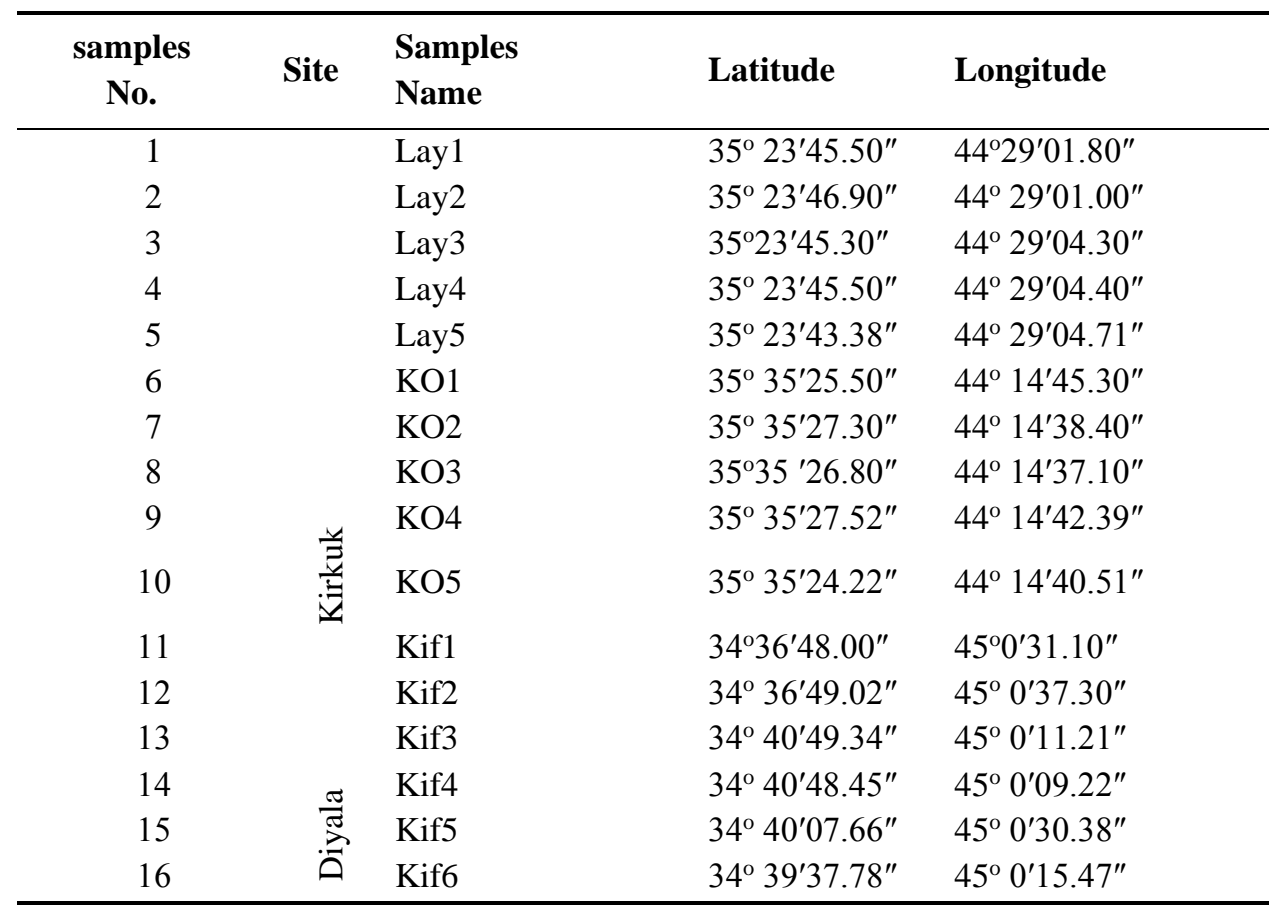

Table 2. Classification of Geo-accumulation index (Muller, 1979)

\begin{tabular}{ccc}
\hline Class & Igeo $_{\text {value }}$ & Description \\
\hline 0 & $0 \geq \mathrm{I}_{\text {geo }}$ & Unpolluted \\
1 & $1 \geq \mathrm{I}_{\text {geo }}>0$ & Unpolluted to moderately polluted \\
2 & $2 \geq \mathrm{I}_{\text {geo }}>1$ & moderately polluted \\
3 & $3 \geq \mathrm{I}_{\text {geo }}>2$ & moderately to strongly polluted \\
4 & $4 \geq \mathrm{I}_{\text {geo }}>3$ & strongly polluted \\
5 & $5 \geq \mathrm{I}_{\text {geo }}>4$ & strongly to extremely polluted \\
6 & $5<$ Igeo & extremely polluted \\
\hline
\end{tabular}

\subsubsection{Health Risk Index Determination (HRI)}

The Evaluation of health risk potential was determined by consuming geophagy marl using the Health Risk Index (HRI) (US EPA 1989). The health risk index is the ratio between exposure to specific trace element and the Oral Reference Dose (RfD) for such an element, which provides an indication of the level of health risks from exposure to pollutants (Lar et al., 2014). In this case, it is obtained by the equation:

$$
\mathrm{HRI}=\frac{D I C * C}{R D * B w}
$$

Where DIC is considered to be $0.02 \mathrm{~kg} /$ day; $\mathrm{C}$ is the measured trace element concentration in the geophagical marl (in ppm); RD is the oral reference dose for the trace element $(\mathrm{mg} / \mathrm{kg}$ of body weight/day) and BW is the average human body weight $(\mathrm{kg})$. 


\section{Results and Discussion}

\subsection{Concentration of Geochemical Elements and their Assessment Indices}

The chemical elements that are naturally present in the human body help it to perform the vital functions which are necessary for the body and its health (Aydogan and Incekara, 2017; Al-Maadhidi, 2019). $\mathrm{Cu}$ and $\mathrm{Zn}$, but have toxic effects at elevated concentrations (Wong et al., 2006). Heavy metals are the more toxic trace element, they include: $\mathrm{As}, \mathrm{Pb}, \mathrm{Hg}, \mathrm{Cr}$ and $\mathrm{Cu}$ (Albayati, 2017). All these elements are derived through ingestion, inhalation and dermal. The effects of regional geology and processes related with soil-forming of an area have a direct impact on the chemical composition of the geophagic marl (Lar et al., 2014). In addition, human activities are among the most common sources of trace elements, such as urban road construction, agriculture, waste burning (Abaha et al., 2014). The results of the chemical contents of the studied geophagy marl are shown in Table 3, the geoaccumulation index (Igeo) values are illustrated in Table 4 and HRI values for the trace elements are presented in Table 5 .

Table 3. The concentration of major and trace elements in studied samples.

\begin{tabular}{ccccccccccc}
\hline ppm & $\mathbf{A l}$ & $\mathbf{C a}$ & $\mathbf{M g}$ & $\mathbf{F e}$ & $\mathbf{N a}$ & $\mathbf{C o}$ & $\mathbf{N i}$ & $\mathbf{C u}$ & $\mathbf{C r}$ & $\mathbf{Z n}$ \\
\hline Max & 60175.73 & 170598.9 & 49876.37 & 52701.62 & 3635.11 & 17.34 & 115.38 & 235.43 & 89.17 & 112.41 \\
Min. & 37523.83 & 142797.1 & 26657.02 & 30470.55 & 1261.16 & 12.02 & 110.01 & 28.92 & 49.84 & 73.49 \\
Ave. & 46360.09 & 156248.3 & 38824.56 & 38862.26 & 2203.94 & 13.97 & 112.81 & 137.12 & 64.423 & 84.81 \\
\hline
\end{tabular}

Table 4. Geo-accumulation index in studied marl samples

\begin{tabular}{cccccccccccc}
\hline & $\mathbf{A l}$ & $\mathbf{C a}$ & $\mathbf{M g}$ & $\mathbf{F e}$ & $\mathbf{N a}$ & $\mathbf{K}$ & $\mathbf{C o}$ & $\mathbf{N i}$ & $\mathbf{C u}$ & $\mathbf{P}$ & $\mathbf{C r}$ \\
\hline Max & 0.334 & 2.122 & 1.078 & 0.476 & 0.058 & 0.291 & 0.230 & 0.680 & 1.863 & 0.220 & 0.305 \\
Min. & 0.208 & 1.776 & 0.576 & 0.275 & 0.020 & 0.126 & 0.219 & 0.662 & 1.034 & 0.262 & 0.235 \\
Ave. & 0.258 & 1.943 & 0.839 & 0.351 & 0.035 & 0.189 & 0.238 & 0.663 & 0.372 & 0.206 & 0.227 \\
\hline
\end{tabular}

Table 5. Health risk index in studied Marl samples for children and adults

\begin{tabular}{|c|c|c|c|c|c|c|c|c|c|c|c|c|}
\hline & & Co & $\mathrm{Ni}$ & $\mathrm{Cu}$ & $\mathrm{Cr}$ & $\mathrm{Zn}$ & & Co & $\mathrm{Ni}$ & $\mathrm{Cu}$ & $\mathrm{Cr}$ & $\mathrm{Zn}$ \\
\hline Max. & & 1.084 & 7.211 & 7.357 & 37.15 & 0.468 & & 0.248 & 1.648 & 1.682 & 8.492 & 0.107 \\
\hline Min. & Child & 0.751 & 6.876 & 0.904 & 20.77 & 0.306 & Adult & 0.172 & 1.572 & 0.207 & 4.747 & 0.07 \\
\hline Ave. & & 0.873 & 7.05 & 4.285 & 26.84 & 0.353 & & 0.2 & 1.612 & 0.979 & 6.136 & 0.081 \\
\hline
\end{tabular}

\subsection{Major Elements Distribution in Geophagic Marl}

$\mathrm{Ca}$ and $\mathrm{Al}$ display relatively higher concentration than the other elements with average $156248 \mathrm{ppm}$ and $46360 \mathrm{ppm}$, respectively (Table 3), depending on the region that it came from (Othman et al., 2020). $\mathrm{Fe}, \mathrm{Mg}, \mathrm{Na}$ and $\mathrm{K}$ average concentration are 38862, 38825,2204 and $10813 \mathrm{ppm}$ respectively (Table 3). Apparently, the levels of the major element ( $\mathrm{Ca}$. Al, Fe, $\mathrm{Mg}, \mathrm{Na}$ and $\mathrm{K}$ ) concentrations determine their benefits and harmfulness when digested into the system of the human body. The geo-accumulation index (Igeo) for these chemical elements display values (Igeo > 1) higher than $1 \mathrm{for} \mathrm{Ca}$, and less than 1 for others, which indicate that the studied marl samples are uncontaminated by these chemical elements except Ca was contaminated (Table 4). 


\subsection{Trace Elements Distribution in Geophagic Marl}

The trace elements like $\mathrm{Cr}, \mathrm{Co}, \mathrm{Cu}, \mathrm{Ni}$ and $\mathrm{Zn}$ display average concentration of $65.65,14.23$, 131.73, 112.99 and $85.61 \mathrm{ppm}$, respectively (Table 4). All of these chemical elements have geoaccumulation index (Igeo) values less than 1 and are below contamination levels except $\mathrm{Cu}$ which show values more than 1 and can be considered as a contamination hazard. Their trace elements concentration levels in the marl are therefor in acceptable quantities and could be considered as a significant source of benefit mineral nutrient that can complement food source but attention should be paid to the $\mathrm{Cu}$ high concentrations which can be harmful.

\subsection{Potential Human Health Risks}

Co and Zn show an HRI less than 1, which means that there are no potential problems with these two elements. Whereas, $\mathrm{Cu}, \mathrm{Cr}$ and $\mathrm{Ni}$ values of HRI are more than 1 , which mean it can cause a serious health problem for children (Table 5). For adults $\mathrm{Co}, \mathrm{Cu}$ and $\mathrm{Zn}$ values are less than 1, while $\mathrm{Ni}$ and $\mathrm{Cr}$ values of HRI are more than 1 (Table 5). Cr tends to cause kidney failure, lung cancer, and dermatitis (Adriano, 2001; Cefalu and $\mathrm{Hu}, 2004$ ). Also, excess $\mathrm{Cu}$ has adverse effect on physiological processes such as: renal insufficiency, nausea and diarrhea (Oyebanjo et al., 2020, Awadh, 2015). Petzold and AlHashimi (2011) explained that the Ni plays an important role in the iron absorption by the human body and is vital for building vigorous bone structures, while the toxicity of Ni can lead to miscarriages and musculoskeletal defects (Vaktskjold et al. 2008). Zinc is generally considered non-toxic, but it can cause dehydration, vomiting, abdominal pain, nausea, dizziness, decreased muscle coordination, and kidney failure (Ekosse and jumbam, 2010).

\section{Conclusions}

Geophagic marl consumption poses health risks to the consumer in terms of its trace elements content. The practice of geophagia contributes to large levels of beneficial elements such as $\mathrm{Fe}, \mathrm{Ca}, \mathrm{K}$, $\mathrm{Na}, \mathrm{Cu}$ and $\mathrm{Zn}$, consequently providing the deficient mineral nutrients that the human body requires it. The Geo-accumulation values of $\mathrm{Ca}, \mathrm{Mg}$, and $\mathrm{Cu}$ are more than 1, which means the geophagic marl is contaminated with them. But geophagic marl is uncontaminated with $\mathrm{Al}, \mathrm{Fe}, \mathrm{Na}, \mathrm{K}, \mathrm{Co}, \mathrm{Ni}, \mathrm{Cr}$ and $\mathrm{Zn}$, which values are less than 1 . Co and $\mathrm{Zn}$ values of HRI are less than 1, which means they have not any adverse health effects. HRI values for $\mathrm{Cu}, \mathrm{Cr}$ and $\mathrm{Ni}$ are more than 1 for children. For adults $\mathrm{Co}, \mathrm{Cu}$ and $\mathrm{Zn}$ values are less than $1, \mathrm{Ni}$ and $\mathrm{Cr}$ values are more than 1 . They can cause a serious health problem for practitioners.

\section{Acknowledgements}

The authors would like to thank Prof. Dr. Yusuf K. Kadioğlu for his help during laboratory analysis which was carried out in the Ankara University, Earth Science Research and Application Center (YEBIM), Turkey. Also, thanks are due to K1 hospital staff, Azadi teaching hospital staff and also the Kifri district administration for their help with samples and their processing. The authors are very grateful to the Editor in Chief Prof. Dr. Salih M. Awadh, the Secretary of Journal Mr. Samir R. Hijab and the Technical Editors for their great efforts and valuable comments.

\section{References}

Adriano, D. C., 2001. Trace elements in terrestrial environments: biochemistry, bioavailability and risk of metals. Springer, Berlin.

Alanazi, N. H., Bohassan, E. A. A., Alsabi, A. F., Bohassan, R. H. A., \& Alenazi, A. H. N., 2018. Iron deficiency anemia with pica syndrome in 5 years old child. The Egyptian Journal of Hospital Medicine, 73(4), 6577 6580 . 
Al-Banna, A.S. and Daham, A.N., 2019. Tectonic boundaries and depth estimate of some gravity sources in Diyala Area, East Central Iraq. Iraqi Journal of Science, 60(2), 308-320.

Al-Hamdani, J.A.J., Awadh, S.M. and Ibrahim, O.S., 2016. Geochemical partitioning of heavy metals in the urban soil, Kirkuk, Iraq. The Iraqi Geological Journal, 39-49 (1). 1-24.

Awadh, S.M., 2015. Cd, Ni, and Pb distribution and pollution assessment in roadside dust from Baghdad City and Western Iraqi Desert. Arabian Journal of Geosciences, 8(1), 315-323.

Çakar, G., \& Şener, M., 2009. Toprak Yeme Hastalığı (Jeofaji) ve Jeoloji: İç Anadolue dan örnek bir çalışma.Tıbbi Jeoloji Çalıştayı, 204-207.

Cefalu, W. T., \& Hu, F. B., 2004. Role of chromium in human health and in diabetes. Diabetes care, 27(11), 2741 2751.

Dissanayake, C. B., and Chandrajith, R., 2009. Introduction to Medical Geology. Springer Science \& Business Media .

Dupont, C., Moreno, J.L., Barau, E., Bargaoui, K., Thiane, E., Plique, O.,1992. Effect of diosmectite on intestinal permeability changes in acute diarrhea: a double-blind placebo-controlled trial. Journal of Pediatric Gastroenterology and Nutrition, 14, 413-419.

Ekosse, E. G. I., \& Jumbam, N. D., 2010. Geophagic clays: Their mineralogy, chemistry and possible human health effects. African Journal of Biotechnology, 9(40), 6755-6767.

Fouad S. F., 2012.Western Zagros Fold-Thrust Belt, Part I: The low folded zone. Iraqi Bulletin Geology and Mining, (5), 39-62.

Gupta, A., 2020. Geophagia: History, Epidemiology and Etiology. CRC Press.

Haris, H., Looi, L. J., Aris, A. Z., Mokhtar, N. F., Ayob, N. A. A., Yusoff, F. M., and Praveena, S. M., 2017. Geoaccumulation index and contamination factors of heavy metals $(\mathrm{Zn}$ and $\mathrm{Pb})$ in urban river sediment. Environmental Geochemistry and Health, 39(6), 1259-1271.

Henry, J., \& Cring, F., 2012. Geophagy. Soils and Human Health, 179-198.

Hooda, P. S., Henry, C. J. K., Seyoum, T. A., Armstrong, L. D. M., \& Fowler, M. B., 2002. The potential impact of geophagia on the bioavailability of iron, zinc and calcium in human nutrition. Environmental Geochemistry and Health, 24(4), 305-319.

Hooda, P. S., Henry, C. J. K., Seyoum, T. A., Armstrong, L. D. M., \& Fowler, M. B., 2004. The potential impact of soil ingestion on human mineral nutrition. Science of the Total Environment, 333(1-3), 75-87.

Johnson, D.M., Hooper, P.R., and Conrey, R.M., 1999. XRF Analysis of rocks and minerals for major and trace elements on a single low dilution li-tetraborate fused bead, International Centre for Diffraction Data, 843867.

Kawai, K., Saathoff, E., Antelman, G., Msamanga, G., and Fawzi, W. W., 2009. Geophagy (soil-eating) in relation to anemia and helminth infection among HIV-infected pregnant women in Tanzania. The American Journal of Tropical Medicine and Hygiene, 80(1), 36-43.

Lar, U. A., Agene, J. I., and Umar, A. I., 2015. Geophagic clay materials from Nigeria: a potential source of heavy metals and human health implications in mostly women and children who practice it. Environmental Geochemistry and Health, 37(2), 363-375.

Mason, B., 1966. Geochemistry and meteorites. Geochimica et Cosmochimica Acta, 30(4), 365-374.

Monaco, E. T., Borries, C., Nikolei, J., Chalise, M. K., Ganzhorn, J. U., Wesche, K., \& Koenig, A., 2019. The function of geophagy in Nepal gray langurs: Sodium acquisition rather than detoxification or prevention of acidosis. American Journal of Physical Anthropology, 168(1), 170-179.

Muller, V.G.,1979. Schadstoffe in Sedimenten-Sedimente als Schadstoffe.107-126.

Odewumi, S. C., 2015. Mineralogy and geochemistry of geophagic clays from share area, Northern Bida Sedimentary Basin, Nigeria. African Journal of Natural Sciences, 16, 1119-1104.

Othman, S.M., Sarsam, S.I., and Ismail, S.A., 2020. Gypsum and limestone dissolution within Fatha Formation (middle miocene) at various ph solutions: a laboratory study. Iraqi Geological Journal, 53(2B), 71-88 .

Oyebanjo, O., Ekosse, G. I., and Odiyo, J., 2020. Health risk evaluation of trace elements in Geophagic Kaolinitic clays within eastern Dahomey and Niger Delta Basins, Nigeria. International Journal of Environmental Research and Public Health, 17(13), 4813. 
Pain, S., Fauconneau, B., Bouquet, E., Vasse-Terrier, L., \& Pérault-Pochat, M. C., 2019. Severe craving associated with kaolin consumption. Eating and Weight Disorders-Studies on Anorexia, Bulimia and Obesity, 24(2), 379-381.

Petzold, K., \& Al-Hashimi, H. M., 2011. RNA structure: Adding a second dimension. Nature chemistry, 3(12), 913.

Reid, R. M., 1992. Cultural and medical perspectives on geophagia. Medical Anthropology, 13(4), 337-351.

Schmidts, T., \& Rusch, V., 2019. Smectite for Medical Use and Their Toxin Binding Capacity. Journal of Food, 3(1), 16.

Timothy, E., Tour, L., 1989. Analysis of rocks using x-ray fluorescence spectrometry. The Rigaku Journal, 6(1), 3-9

U. S. Environmental Protection Agency,1989. Risk Assessment Guidance for Superfund Volume 1: Human Health Evaluation Manual (Part A). Office of Emergency and Remedial Response: Washington, D.C., USA.

Vaktskjold, A., Talykova, L. V., Chashchin, V. P., Odland, J. Ø., and Nieboer, E., 2008. Spontaneous abortions among nickel-exposed female refinery workers. International Journal of Environmental Health Research, 18(2), 99-115.

Vutchkov, M., Lalor, G., and Macko, S., 2013. Inorganic and organic geochemistry techniques. In Essentials of Medical Geology. Springer, Dordrecht ,689-716.

Wilson, M. J., 2003. Clay mineralogical and related characteristics of geophagy materials. Journal of Chemical Ecology, 29(7), 1525-1547. 